\title{
Implementation of TOPSIS (Technique for Order of Preference by Similarity to Ideal Solution) in Determining Poverty Ranking of Village Communities as Recommendations for Government Assistance
}

\author{
Hasbul Bahar ${ }^{*}$, Moh. Ainol Yaqin ${ }^{2}$ \\ ${ }^{1,2}$ Informatics Study Program, Faculty of Engineering, University of Nurul Jadid, Karanganyar, Paiton, \\ Probolinggo \\ *Corresponding Author \\ E-mail: hasbulbahar@unuja.ac.id*
}

\begin{abstract}
Since the monetary crisis that hit Indonesia in 1998 it has become a scourge tense for the State of Indonesia. Every year it increases, this thing one of the reasons is the increasing price of food, clothing and food. In response to this, the government has provided several economic assistance, such asFamily Hope Program, KIP (Smart Indonesian Family) and assistance provided by the government. However, there is a lot of assistance the community, especially in the village, admitted to being poor to get this assistance. So that aid was not on target, causing unequal distribution of aid to the community who are indeed poor in accordance with government criteria, as happened, around 1,443 assistance was leveraged or double-checked because it was not right on target. Therefore, we need a ranking concept that is right on target and according to the criteria who are entitled to get assistance from the government by using the TOPSIS method as a recommendation who is entitled to assistance from the government. The fundamental reason for choosing this method is because of the level of complexity so that it has high accuracy when compared to others. And the method will be created using a website, so that it is easily accessible in all places. So, calculating the TOPSIS aims to see the poor in accordance with the criteria set by the government as a recommendation for providing assistance to truly poor people.
\end{abstract}

Keywords: Poverty, Helping, TOPSIS, Website.

\section{INTRODUCTION}

In mid-1997 to 1998 poverty in Indonesia increased drastically, this was caused by the economic crisis that hit the Indonesian [1]. The problem of poverty is complex and multidimensional because it relates to social, economic, cultural and structural dimensions. The Indonesian Central Bureau of Statistics (2015) reported that the poverty rate in Indonesia was $10.96 \%$ in 2014 . Although the poverty rate in that country has decreased by $1.27 \%-1.78 \%$ from 2004 to 2009; but that reduction rate slowed down by $0.4 \%-0.8 \%$, then in general, this indicates that the government has failed to reduce poverty to $7.55 \%$ nationally in Indonesia 2017 as stipulated by the Ministry of National Development Planning / National Development Planning Agency PT Republic of Indonesia [2]. Kemenko PMK or abbreviated as the Coordinating Ministry for Human Development and Culture, Perprs No.9 of 2015 that Kemenko PMK has the responsibility in terms of synchronization, coordination and control of human development and culture. One of the aspects of this is the society prosperity aspect, which is applied in the form of 
social assistance to the community. The provision of such assistance is intended to provide security for food needs and to increase the standard of living for social assistance recipients or abbreviated as Social Assistance. s for several social assistance activities such as PIP/TPP or abbreviated as the Indonesia Pinta Program, JKN-KIS or the National Health Insurance Program, which are often obtained by the wider community, are FHP/PKH (Family Hope Program) and Rastra Non-cash food assistance and many other assistance programs from the government. One of the ways to solve the problem of poverty is by committing to expanding social assistance (social assistance) programs evenly and on target. These efforts paid off by looking at the graph of the reduction in poverty ratio. From $11.22 \%$ in 2015, in 2018 it became $9.82 \%$.

By this assistance, the Central Statistics Agency (CSA/BPS) noted that it had reduced the poverty rate gradually but it was unstable, this is because the determination of the poor is not in accordance with the stated criteria, it is only a presumption and even rich families get help from the government, such as the Indonesian Ministry of Social Affairs (Kemensos) issued 1,443 Pidie residents as recipients of the Hope Family Program (HFP/PKH) assistance[3]. So that the aid is evenly ranked, structured and systematic according to the existing criteria, this research will apply the TOPSIS (Technique for Order of Preference by Similarity to Ideal Solution) method to measure the worthiness of getting help. The basic reason for using the TOPSIS method is because the method is more complex than SAW method or others, so that the accuracy of the TOPSIS is greater[3]. This implementation will use a website, with the aim of being easily accessible without any time and place restrictions. The place of research or case studies will be carried out in the village of Tlogosari, Districts. Tlogosari District. Bondowoso, East Java with a population of 2583 families (heads of families). The average occupation of the population there is a farmer, with this type of work, sometimes it is difficult to determine the validity of those who are entitled and not in getting assistanc. Therefore, by the help of the TOPSIS method, it will be easier to determine who is entitled or note. Where by the conditions of this type of work, the criteria will be taken according to the Family Mapping (FM) Questionnaire Instrument in the Context of Independent Prosperity Graduation for the Family Hope Program (FHP/PKH) of East Java Province as follows: (1). Main Parameters (Conditionality of KPM). (2). Home Condition Parameters. (3). Asset Ownership Parameters. (4) Work / Business Parameters and Family Economic Burden. And lastly is a list of fields in the form of skills that can increase income. Of the four criteria, there will be priority values in percentage terms, assets $(40 \%)$, house conditions (30\%), income or business (20\%) and conditionality parameters of KPM (10\%), these values are obtained from interviews with PKH members.

The TOPSIS method is used to determine the best alternative from the compromise solution concept. TOPSIS method for MADM (Multiple Attribute Decision Making) in a simplified neutrophic environment [4]. There are many methods for ranking one of the journals with the title Decision Support System for Recipient Recommendations for the Family Hope Program (FHP/PKH) Using the Simple Additive Weighting (SAW) Method[5]. These journals have similarities in terms of cases, namely determining rankings to get help, but different methods are between the current research TOPSIS and the previous research SAW method. The SAW method is the simplest and easiest MADM (Multiple Attribute Decision Making) method, because this the level of accuracy of the curling accuracy is less good when compared to TOPSIS, of course the TOPSIS method is better. TOPSIS stands for Technique for Order of Preference by Similarity to Ideal Solution. The first step is to calculate the normalized matrix with the following formula: 


$$
R_{i j}=\frac{x_{i j}}{\sqrt{\sum_{i=1}^{m} x_{i j}^{2}}} \text { where } i=1,2 \ldots, m \text { and } j=1,2 \ldots, n
$$

Then perform the calculation in a matrix to become normalized so that it is weighted (Y) where the weight value is written (W) the application of the formula is: Formula: yij = wi $*$ rij; where $\mathrm{i}$ $=1,2, \ldots, m$; and $\mathrm{j}=1,2, \ldots, \mathrm{n}$. Next find the value of $\mathrm{A}+$ or Positive Ideal Solution and value (A-) or Negative Ideal Matrix.

And the calculation method: $\mathrm{A}+=\max (\mathrm{y} 1+, \mathrm{y} 2+, \ldots, \mathrm{yn}+)$ and $\mathrm{A}-=\max (\mathrm{y} 1-, \mathrm{y} 2-, \ldots, \mathrm{yn}-$ ). And determine the value ( + ) or Positive Ideal Solution Distance and value (D-) or Negative Ideal Solution.

The formula for calculating it:

$$
D_{i}^{+}=\sqrt{\sum_{j=1}^{n}\left(y_{i}^{+}-y_{i j}\right)^{2}} i=1,2 \ldots, m
$$

The final stage is to find the value of the Preferences for each alternative, the formula:

$$
V_{i}=\frac{D_{i}^{-}}{D_{i}^{-}+D_{i}^{+}}, \text {where } i=1,2,3 \ldots, m \text {. }
$$

The ranking rule is $\mathrm{V} 2>\mathrm{V} 4>\mathrm{V} 5>\mathrm{V} 1>\mathrm{V} 3$ this value indicates that the value of $\mathrm{V} 2$ is the highest value or greater.

The definition of bootstap is contained in the official page https://getbootstrap.com/, Bootstrap is a design layout framework or commonly called the front-end, CSS, HTML, and is designed in developing to make website pages responsive. The journal explains about the implementation of Bootstrap to make the site fit with the existing platform[6]. To use the Bootstrap service, you must first use HTML 5 and above and the required links must be linked. By using this media, website building will be faster, more attractive and interactive. PHP or PHP Hypertext Preprocessor is a programming language designed for the purpose of enabling dynamic content creation [7]. The TOPSIS calculation algorithm will be synchronized using PHP and as a liaison with the database or called the back end. Calling inner queries to perform CRUD (Create, Read, Update and Delete), using PHP syntax, or called a link to the database. MySQL is not a database but is called RDBMS or database relational database management system which is distributed free of charge and under the General Public License (GPL) [8]. MySQL and SQL are a unit where there is SQL in MySQL, the word QL is a query to be able to access the database. SQL in 1970 was defined as the ISO and ANSII standard. DataTables is a plug-in [9], devoted to displaying existing data automatically, sorting data, searching data and data pagging. Usually, these dataTables can accompany a lot of data or commonly known as big data. Usually, these dataTables can accompany a lot of data or commonly known as big data.

\section{METHODOLOGY}

The research method for designing and making the application of the Technique for Order of Preference by Similarity to Ideal Solution or TOPSIS method as a reference for the government in providing poverty assistance to the village community so that it is appropriate to those who are entitled as follows: 


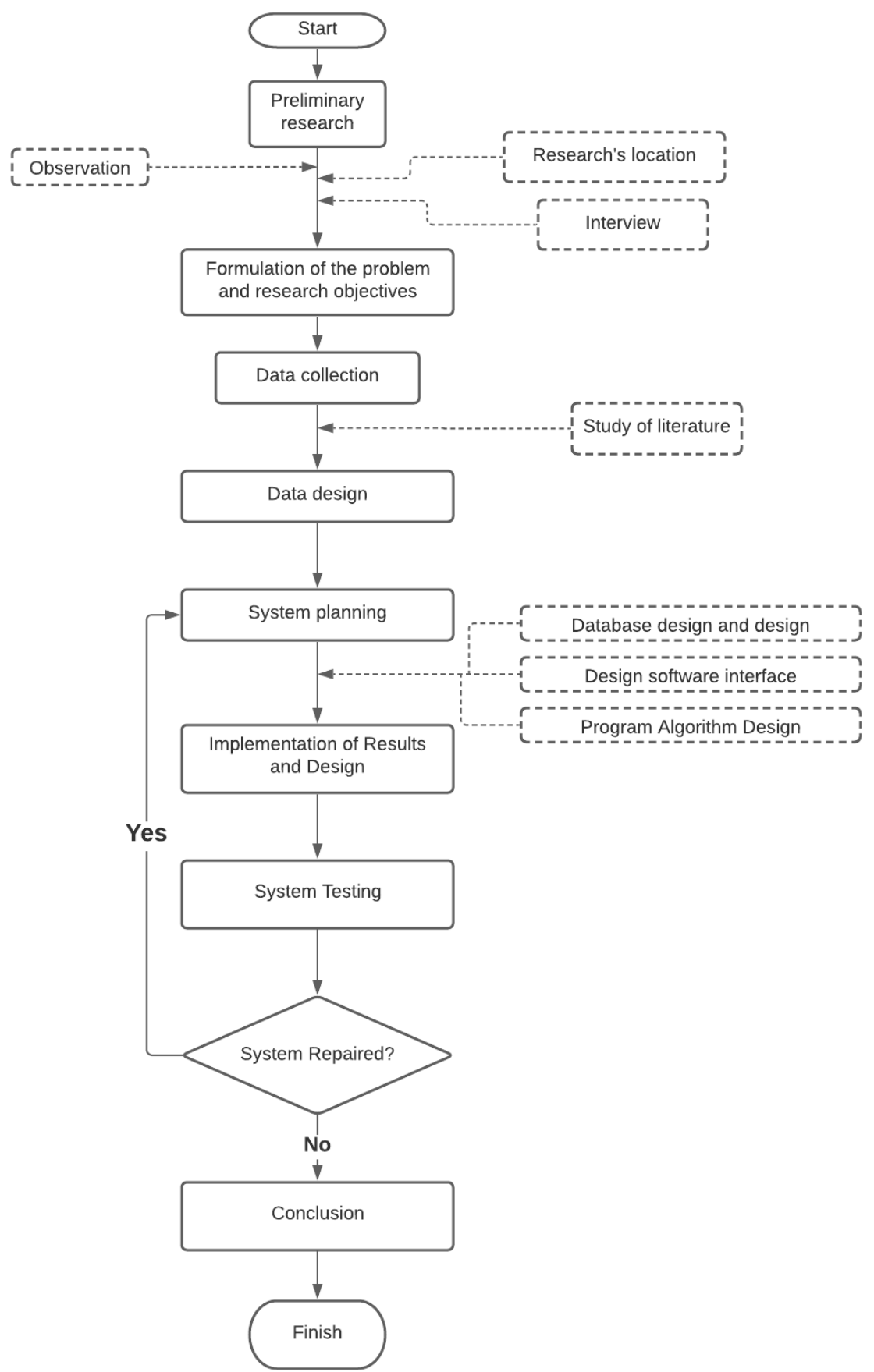

Figure 1. Stages of Research Methods

\section{A. Preliminary Research}

In early research to find and determine the object of research, analyze the problems that occur and the possibility to conduct research and obtain data. The stage is by visiting while conducting an observation to Tlogosari Village, Tlogosari District, Bondowoso Regency however, by still paying attention to and implementing health protocols, then conducting interviews with the 
relevant village heads. Furthermore, the results of observations and interviews are discussed again with the team to determine the next steps to be taken. Then the results of the preliminary determination and previous discussions showed that the problems that had occurred so far were that some people in the area claimed to be poor even though after checking it did not match the criteria set by the government. So with the application of the TOPSIS method will be used to see and determine the ranking value for reference data that has received assistance from the government, a recommendation in determining the poor and indeed entitled to assistance from the government. Of course, with the criteria according to the Family Mapping (FM) Questionnaire Instrument in the Context of Independent Prosperity Graduation for the Family Hope Program (FHP/PKH), East Java Province.

\section{B. Problem Formulation and Research Objectives}

At the initial research stage, the results of the analysis showed that in Tlogosari Village, Tlogosari District, Bondowoso Regency, they still used conventional steps to determine poor families so that they received assistance from the government. And in fact there are some villagers who claim to be poor to get help. From the application that we will create will make it easier to make decisions for the government to determine who will be eligible for assistance, as a reference for providing assistance in accordance with the criteria.

\section{Data collection}

Next is data collection, the goal is that the initial data are basic requirements to design the system with the results of observations in support of finding the poverty level ranking value with criteria guidance and interviews where those who have related data are carried out, then some of the results are in the files needed to support the research. Furthermore, the study of literature is needed to have written data as a supporting reference in knowing about the necessary research such as TOPSIS algorithms, system design, database design used in systems such as data flow charts, entity relationship diagrams and flow of applications. The study of literature is from reading books about IT, related journals and research documents that have been carried out.

\section{System planning}

System design is practically a process flow to complete applications that will be completed with conceptual and organized rules according to the results of observations and interviews. The system design flow has several stages as follows: (1) The concept of linking the data field to other fields forms a proper flow and holds the concept of needs such as: one to one, one to many or many to many, the last concept will display a new field or entity. (2) The concept of human relations with the system or called UI (User Interface) and UX (User Experience). Both are rules so that the use of the application is user friendly and the layman easy to use it. (3) The final stage of iteration, either in terms of algorithm or syntax, is required.

\section{E. Implementation of Design Results}

The implementation stage is to take from the previous stage, namely the system design found in points 2 and 3. The follow-up is more directed at filling, entering the TOPSIS method into the application by programming algorithms, designing the interface or interface and managing the 
DBMS server system. In order to make it easier for coding will be done with a framework system to get good results in terms of security and management of the system properly and efficiently.

\section{F. System Testing}

System testing is carried out when the application is ready and ready for use. Aims to find out bugs or application errors. The system tester is the user, or the person who will use the application. There are two things in system testing, first looking for bugs or errors, then fixing them until they are expected. Second, it monitors whether it is comfortable to use or not, usually called user friendy. If the two data is lacking, it will be repaired again.

\section{G. Conclusion}

The conclusion stage is the last stage. This stage concludes that there is an overall application, in terms of the process of retrieving data from database design, interface design and application coding and application of the TOPSIS method. If the reporting answers from the research formulation and is contained in the writing of the conclusions in the last section. The research achievement is answered in the conclusion sectionah:

\section{RESEARCH RESULT AND DISCUSSION}

In the village of Tlogosari, Districts. Tlogosari District. Bondowoso East Java with a population of 2583 families (heads of families). The average occupation of the population there is a farmer, with this type of work, sometimes it is difficult to determine the validity of those who are entitled and not in getting assistance. In reducing the level of poverty crisis of the community, the government has implemented and applied evenly in the village community direct assistance, abbreviated as KSM (Very Poor Families)[10]. The assistance is called the Hope Family Program (HFP/PKH), the assistance was specifically for Very Poor Households, abbreviated as VPH/RTSM the provision is that family members have children at the age of 0-15 years or 15-18 years and have not completed elementary school education and pregnant or postpartum mothers [11]. In determining who has the right to receive or not by using the TOPSIS method. The purpose of this method is to determine rankings[12], where with the highest's ranking value the more entitled to receive assistance. The formula for the TOPSIS method is in accordance with the TOPSIS discussion on the theoretical basis. The criteria used for this application are. according to the Family Mapping (FM) Questionnaire Instrument in the Context of Independent Prosperity Graduation for the Family Hope Program (PKH) of East Java Province.

Table 1 Family Mapping Criteria

\begin{tabular}{|c|l|c|}
\hline NO & Code & Name Criteria \\
\hline 1. & K01 & $\begin{array}{c}\text { Main Parameters } \\
\text { (Conditionality of KPM) }\end{array}$ \\
\hline 2. & K02 & Home Condition Parameters \\
\hline 3. & K03 & Asset Ownership Parameters \\
\hline
\end{tabular}




\begin{tabular}{|c|l|c|}
\hline 4. & K0[13] & $\begin{array}{c}\text { Work / Business Parameters } \\
\text { and Family Economic Burden }\end{array}$ \\
\hline
\end{tabular}

Table 2. Family Mapping Criteria Weights

\begin{tabular}{|c|c|c|}
\hline NO & Criteria & Weight (\%) \\
\hline 1. & $\begin{array}{c}\text { Main Parameters } \\
\text { (Conditionality of KPM) }\end{array}$ & $10 \%$ \\
\hline 2. & Home Condition Parameters & $30 \%$ \\
\hline 3. & Asset Ownership Parameters & $40 \%$ \\
\hline 4. & $\begin{array}{c}\text { Work / Business Parameters and } \\
\text { Family Economic Burden }\end{array}$ & $20 \%$ \\
\hline
\end{tabular}

Alternatives are taken from the target population who will be determined whether they have the right or not to receive assistance recommendations. The database design on the TOPSIS application to determine the rankings of those entitled to help will be contained in the ERD (Entity Relationship Diagram). The flow represents the use of fields that will be applied to the TOPSIS Method. Transform the Entity Relationship Diagram into a Logical Record Structure, and the database specifications are used, the contents are as follows:

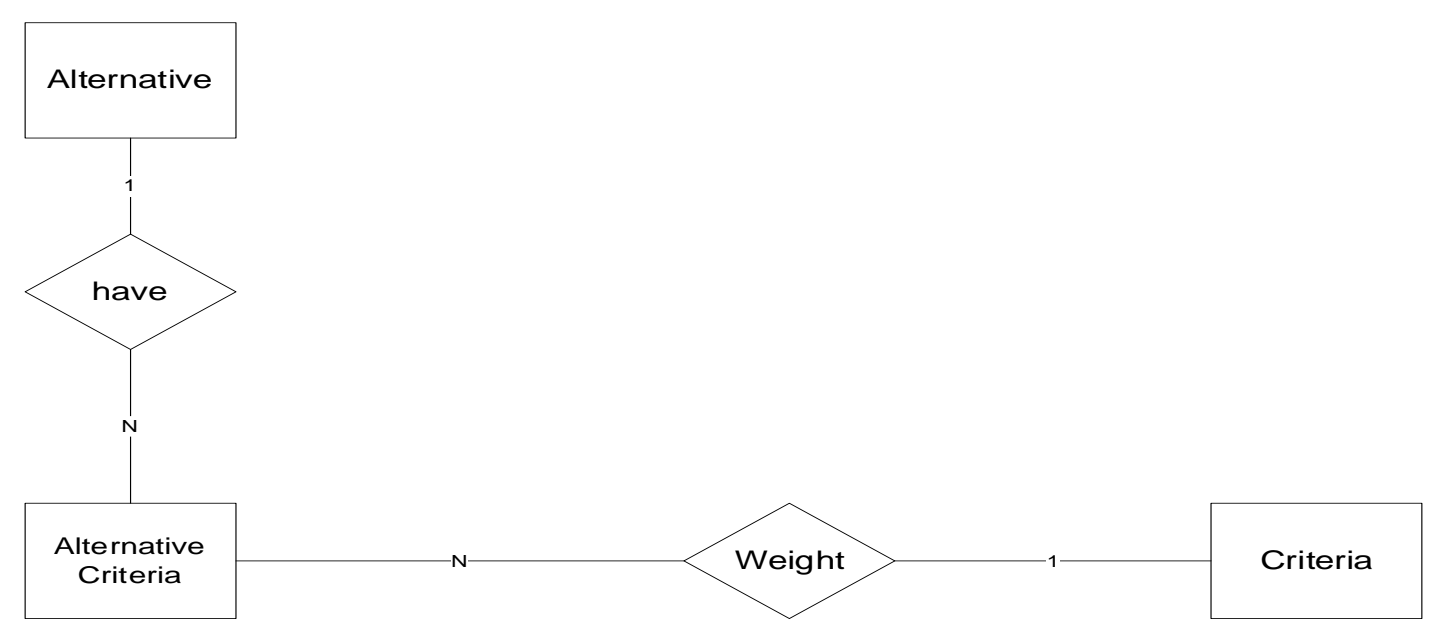

Figure 2. ERD TOPSIS Method

ERD above has a relationship from one alternative entity having many entities alternatifKretasi. And one creative entity weighs many entities alternatifKretasi. The entities alternatifKretasi retrieve data from both Alternative entities and criteria, then calculated using the TOPSIS method, where the weighting value will affect the ranking in determining who is entitled to assistance. After the database system is created, the TOPSIS method runs on the application. Flowchart system using flowchart, there are two flowchart system, application flowchart and TOPSIS method flowchart[14]. 


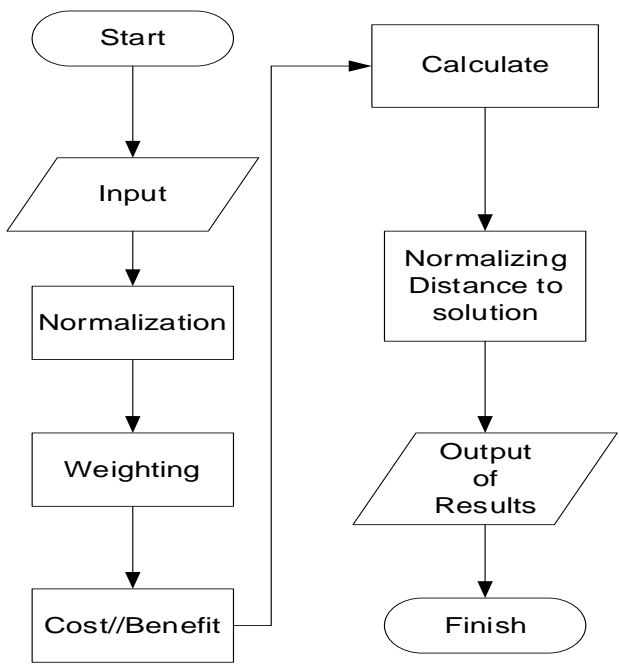

Figure 3. TOPSIS Method flowchart

Next, after the above system, then implementation, implementation of alternative inputs, criteria and values of the alternative criteria are already in the program. The dashboard display is as follows:

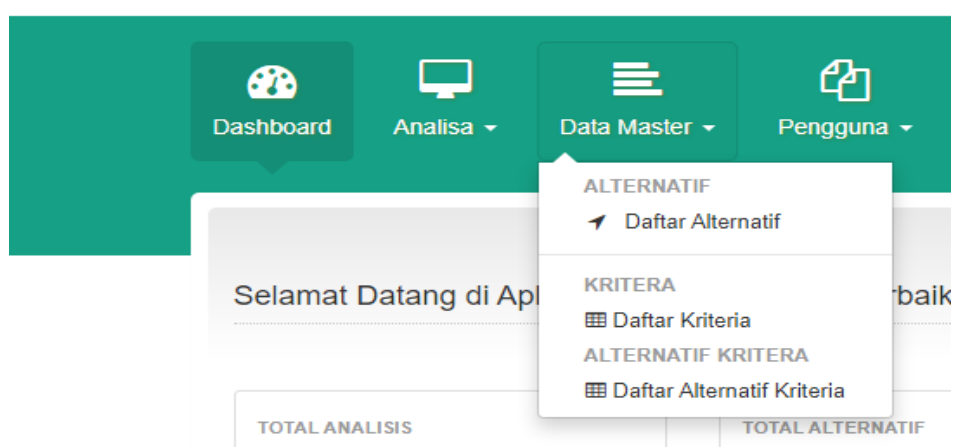

Figure 4. TOPSIS Method program dashboard page

In the trial, there have been 10 alternatives with the value according to the $\mathrm{i}$ nput from the research results, the system will automatically calculate the normalized value, weighted result, preference value and final value in the form of ranking, according to the TOPSIS method[15].

\begin{tabular}{|l|l|l|l|}
\hline Normalization: & & \\
\hline 0.14900763546608 & 0.32828701521667 & 0.27994644592397 & 0.46196443529555 \\
\hline 0.20265038423386 & 0.39394441826 & 0.18663096394931 & 0.32481874356718 \\
\hline 0.23841221674572 & 0.28283189003282 & 0.1807987463259 & 0.24541860625076 \\
\hline 0.1251664137915 & 0.060606833578462 & 0.17496652870248 & 0.25985499485375 \\
\hline 0.33377710344401 & 0.4848546686277 & 0.26244979305372 & 0.11549110882389 \\
\hline 0.46490382265416 & 0.32828701521667 & 0.23328870493664 & 0.52692818400898 \\
\hline 0.26821374383894 & 0.21717448698949 & 0.34993305740496 & 0.35369152077315 \\
\hline 0.51854657142194 & 0.060606833578462 & 0.32077196928788 & 0.3103823549642 \\
\hline 0.39934046304908 & 0.39394441826 & 0.38492636314546 & 0.11549110882389 \\
\hline 0.19072977339658 & 0.3232364457518 & 0.57155732709477 & 0.16601846893434 \\
\hline
\end{tabular}

Figure 5. Results of Normalization with the TOPSIS Method program 
In the program the values above are listed, but what is shown is the result of normalization and the result of the ranking. The following are the results of the ranking using the TOPSIS method.

\begin{tabular}{l|l|l|}
\hline Ranking & Altematif & Nilai \\
\hline 1 & JAMILAH & 0.67935663233308 \\
\hline 2 & LILIK SRI WAHYUNI & 0.62861329054688 \\
\hline 3 & JUMALIA & 0.61200793958641 \\
\hline 4 & SUUDIYAH & 0.60183361736408 \\
\hline 5 & SITI FATIMAH & 0.55540578615885 \\
\hline 6 & MURAHMA & 0.54441217425368 \\
\hline 7 & AISA & 0.48209064151308 \\
\hline 9 & FARDATUL JANNAH & 0.36643090346797 \\
\hline 10 & WASIATUN & 0.30745028696823 \\
\hline & SUSI & 0.2349308699772 \\
\hline
\end{tabular}

Figure 6. Page Ranking Results with the TOPSIS Method program

The final result is a ranking as above. The ranking means that the top value is the most entitled, number two has the right to both and so on. Determination of what rank is entitled to receive assistance according to the quota on the Family Hope Program (FHP/PHK).

\section{CONCLUSION}

The results of this study have produced an application using a website platform applying the TOPSIS method, which is used as a recommendation to get assistance data in the village of Tlogosari, Tlogosari District, Bondowoso Regency, East Java. The Family Mapping Questionnaire (FM) instrument in the context of independent prosperous graduation of the Family Hope Program (FHP/PKH) of East Java Province is used as the criteria and weight of the criteria resulting from interviews with parties handling assistance. The final output of this application is in the form of ranking, where the highest-ranking value is the most recommended for getting help.

\section{REFERENCES}

[1] R. R. Amalia and K. Kadir, "Multidimensional Poverty Index (MPI) in Agricultural Household in Indonesia," 2016.

[2] L. Nansadiqa, R. Masbar, and M. S. A. Majid, "Does economic growth matter for poverty reduction in Indonesia," East African Sch. J. Econ. Bus. Manag., vol. 2, no. 2, pp. 46-52, 2019.

[3] M. Nazar, "1.443 warga pidie dikeluarkan dari penerima bantuan pkh," 2019. https://aceh.tribunnews.com/2019/04/05/1443-warga-pidie-dikeluarkan-dari-penerimabantuan-pkh-diduga-ada-orang-kaya (accessed Jun. 05, 2020).

[4] M. N. Febriyati, M. K. Sophan, and R. Yunitarini, "Perbandingan Saw dan Topsis Untuk Open Recruitment Warga Laboratorium Teknik Informatika Di Universitas Trunojoyo Madura," J. Simantec, vol. 5, no. 3, 2016. 
[5] L. Lestari, "Sistem Pendukung Keputusan Rekomendasi Penerima Bantuan Program Keluarga Harapan (Pkh) Menggunakan Metode Simple Additive Weighting (Saw)," University of Technology Yogyakarta, 2020.

[6] P. Biswas, S. Pramanik, and B. C. Giri, "TOPSIS method for multi-attribute group decision-making under single-valued neutrosophic environment," Neural Comput. Appl., vol. 27, no. 3, pp. 727-737, 2016.

[7] M. Shah, "Responsive web development using the Twitter Bootstrap framework," 2015.

[8] R. C. N. Santi and S. Eniyati, "Implementasi Statistik dengan Database Mysql," Dinamik, vol. 20, no. 2, 2015.

[9] R. Somya and B. Beny, "Pemanfaatan Plug-in DataTables untuk Sistem Informasi di Unit Indostamping PT Pura Barutama," J. Inform., vol. 6, no. 1, pp. 84-90, 2019.

[10] N. Aminudin and I. A. P. Sari, "Sistem Pendukung Keputusan (Dss) Penerima Bantuan Program Keluarga Harapan (Pkh) Pada Desa Bangun Rejo Kec. Punduh Pidada Pesawaran Dengan Menggunakan Metode Analytical Hierarcy Process (AHP)," J. TAM (Technology Accept. Model., vol. 5, pp. 66-72, 2017.

[11] Y. Yuningsih, S. Sumardani, and U. Hani, "Social Protections in Health and Education through the Hope Family Program: A Case Study in Wanayasa Village, Wanayasa SubDistrict, Purwakarta Regency," Asian J. Poverty Stud., vol. 4, no. 1, 2018.

[12] G. Wibisono, A. Amrulloh, and E. I. H. Ujianto, "Penerapan Metode Topsis Dalam Penentuan Dosen Terbaik," Ilk. J. Ilm., vol. 11, no. 2, pp. 102-109, 2019.

[13] F. Duwiyanti and M. Ardhiansyah, "Sistem Pendukung Keputusan Pemilihan Guru Terbaik di SMK Pustek Serpong," Int. J. Educ. Sci. Technol. Eng., vol. 2, no. 1, pp. 4567, 2019.

[14] Y. Efenie and H. Hozairi, "Implementasi Metode Topsis Untuk Analisis Faktor Keberhasilan Pengelolaan Sekolah Berbasis Web," Mnemon. J. Tek. Inform., vol. 2, no. 2, pp. 32-37, 2019.

[15] R. Simanjuntak, M. Safii, and W. Saputra, "Sistem Pendukung Keputusan Pemilihan Siswa Terbaik Dengan Menggunakan Metode Topsis di SMA Sultan Agung Pematangsiantar," in Prosiding Seminar Nasional Riset Information Science (SENARIS), 2020, vol. 2, pp. 331-341. 